ISSN: 2146-3042

DOI: $10.25095 /$ mufad.710367

\title{
Ülke Kredi Temerrüt Takas Primleri ile Hisse Senedi Fiyatları Arasındaki İlişki: Borsa İstanbul'da Banka Hisse Senetleri Üzerine Ampirik Bir Araştırma*
}

\author{
Haşmet SARIGÜL* \\ Hakan Eren ŞENGELEN**
}

\begin{abstract}
ÖZET
Kredi Temerrüt Takasları (CDS) ülkelerin kredi riski ölçümünün ve yatırımcıların ilgili ülkeye dönük risk algısının başlıca belirleyicilerinden birisi olarak kabul edilmektedir. Risk algısındaki değişmenin etkisini en hızlı gösterdiği alanlardan birisi ise hisse senedi piyasalarıdır. Borsa İstanbul'da işlem gören banka hisse senetleri de bundan bağımsız değildir. Bu çerçevede ülkemizin CDS primleri ile BIST Banka Fiyat Endeksi ve bankaların hisse senedi fiyatları arasındaki kısa ve uzun dönemli ilişki araştırılmış ve ülke riski algısının belirtilen piyasa üzerindeki etkileri analiz edilmiştir. Çalışmadazaman serileri arasındaki uzun dönemli ilişkinin varlığını belirleyebilmek için VAR analizine dayalı JohansenEşbütünleşme testi uygulanmıştır. Sinama sonrası Ülke Temerrüt Takasının uzun dönemde BISST Banka Endeksi ile değerleri test edilen beş bankaya etkileriolduğu tespit edilmiştir. Granger Nedensellik Analizi bulgularına göre de ülke CDS'leri ile birbanka arasında iki yönlü nedensellik iliş̧isi belirlenmişs olup tek yönlü nedenselliği bulunan değişken sayısı beştir. Bir bankanınise Ülke CDS'lerininGranger nedeni olduğu görülmüştür.
\end{abstract}

Anahtar Kelimeler: Kredi Temerrüt Takası, BIST Banka Endeksi, Banka Hisse Senetleri

JEL Sinıflandırması: G10, G14, G15

\section{The Link Between Sovereign Credit Default Swaps and Bank Stock Prices:}

\section{An Empirical Study on Bank Stocks in the Borsa Istanbul}

\section{ABSTRACT}

Sovereign CDS is considered as one of the main platform stogauge market views on a country's default risk. One of the areas where the change in risk perception shows them ostrapi deffect is the stock markets. In this context, the short and long term relationship between BIST Bank Price Index, stock prices of banks and Sovereign CDS premiums of Turkey was examined. Johansen Cointegration test was applied to determine whether there exists a long run relationship between time series and observed that CDS premiums of Turkey had an impact on the BIST Bank Index and five bank's stock prices. According to the Granger Causality Analysis, the Sovereign CDS has a two-way causality relationship between one bank and the number of variables with one-way causality is five. A bank was found to be the cause of Granger of Sovereign CDS.

Keywords: CreditDefaultSwaps, BIST Bank Index, Bank StockPrices

Jel Classification: 610, G14, G15

* Makale Gönderim Tarihi: 01.08.2019, Makale Kabul Tarihi: 08.09.2019, Makale Türü: Araştırma Makalesi

* Doç.Dr, İstanbul Esenyurt Üniversitesi İşletme ve Yönetim Bilimleri Fakültesi,hasmetsarigul@esenyurt.edu.tr, Orcid ID: 0000-0001-7262-6668.

** Araştırma Görevlisi, İstanbul Esenyurt Üniversitesi İşletme ve Yönetim Bilimleri Fakültesi, hakansengelen@esenyurt.edu.tr, Orcid ID: 0000-0002-2079-4720 


\section{GíRiş̧}

Ülke riski, bir ülkedeki ekonomik ve politik belirsizliklerin ilgili ülkeye yapılacak olan yatırım kararlarını ve bu yatıımların değerini etkileme olasılığı olarak tanımlanmaktadır. Ülkenin borç yükümlülüklerini yerine getirememe riskini ifade eden ülke riski, ekonomik, siyasi ve sosyal faktörler ile güvenilirlik ve şeffaflık gibi çeşitli unsurların bir sentezidir. Bu terim ayrıca ülkedeki yabancı para finansal araç ihraçcılarının yükümlülüklerini yerine getirebilmelerine engel olabilecek döviz kısıtlamalarına da atıfta bulunmaktadır. Ülke riski, yeniden finansman riskini de içeren bir kavramdır.

Bir ülkeye yönelik risk algısının değerlendirilmesinde kullanılan başlıca göstergelerden birisi Kredi Temerrüt Takası primleridir. CDS bir ülke veya firma tarafından çıkarılan borçlanma araçlarına ait ödemelerin tam ve zamanında gerçekleşmemesi riskine karşı koruma sağlayarak bir tür sigorta işlevi gören finansal türev üründür. CDS primi ise borçlanma aracını piyasalara sunanların temerrüde düşmesi olasılığına karşı, borçlanma aracına yatırım yapmış olanların satın aldıkları sözleşme için ödedikleri primlerdir. İlgili primi ödeyerek sözleşme satın alan yatırımc1, temerrüt durumunda elinde bulundurduğu borçlanma aracını nominal değeri üzerinden sözleşmeyi satana devretme hakkı elde etmektedir. CDS baz puanının yüksek olması temerrüt riskinin de yüksek olduğuna işaret etmektedir. Temel olarak primlerin belirlenmesindeki itici güç ekonomi olmasına karşın bir ülkenin sorunlarını çözme konusundaki belirsizlikler, tutarsızlıklar ve güven eksikliği de risk algısını etkileyebilmektedir.

Bir ülkeye yapılması öngörülen dolaylı veya dolaysız yatırımların karar süreçlerinde de ülke riskinin uygun bir araçla doğru olarak belirlenmesi önemli kabul edilmektedir. CDS'ler ülkelerin kredi riski ölçümünün ve yatırımcıların ilgili ülkeye yönelik risk algısının başlıca belirleyicilerinden biri olarak kabul edilmektedir. Ülkedeki ekonomik sorunların etkilerinin ilk ve en fazla hissedildiği sektörlerden birisi ise bankacılıktır. Borsa İstanbul içerisinde yer alan bankalara yapılan yatırımlar da bundan bağımsız değildir.

Finans literatürünündeki tartışma konularından birisi risk algısındaki değişmenin hisse senedi piyasası üzerindeki etkileridir. $\mathrm{Bu}$ çerçevede ülke riski ile hisse senedi piyasası arasındaki ilişki çeşitli bilim insanları tarafından araştırılmakta ve tartışılmaktadır. CDS primleri ile hisse senetleri piyasası arasındaki ilişkinin belirlenmesine yönelik dünyada ve ülkemizde çeşitli yöntemlerle yapılan çalışmalar bulunmaktadır. Ancak ülkemiz literatüründe banka hisse senetleri fiyatları ile ülke CDS primleri ilişkisi üzerine gerçekleştirilen bir araştırmaya rastlanılmamıştır. Bu kapsamda ülkemizin CDS primleri ile BİST Banka Fiyat Endeksi ve bankaların hisse senedi fiyatları arasındaki kısa ve uzun dönemli ilişki araştırılmış ve ülke riski algısının belirtilen piyasa üzerindeki etkileri belirlenmeye çalışılmıştır. Araştırmada Ocak/2014 ile Haziran/2019 arasındaki döneme ait günlük veriler kullanılmıştır.

Çalışma giriş ve sonuç kısımları ile birliktebeş bölümden oluşmaktadır. İkincibölümde kavramsal çerçeveyeve literatürtaramasının sonuçlarınayer verilmiştir.Üçüncübölümde; veriler, değişkenler ve araştırmada uygulanan yöntemle ilgili bilgiler sunulmuştur.Dördüncü bölümde araştırmanınbulguları paylaşılarak analiz edilmiştir. Beşincibölümde ise sonuçlar irdelenmiştir. 


\section{KAVRAMSAL ÇERÇEVE}

\section{1. Ülke Kredi Temerrüt Takası ve Hisse Senetleri Piyasası}

Kredi riski ölçümü yaklaşımlarının başında yıllardır kredi derecelendirme sistemleri gelmektedir. Bilinen en eski kredi riski göstergeleri Moody's, Standart\&Poors ve Fitch gibi kredi derecelendirme kuruluşlarının verdiği notlar ve yaptıkları analizlerdir. Derecelendirme kuruluşları, finansal piyasalardaki asimetrik bilgi sorunlarını azaltan önemli kurumlardır. Her ne kadar bu kuruluşların sistemleri farklılık gösteriyor olsa daborç alanların göreli risklerini ayırt etmede makul derecede başarılı oldukları kabul edilmektedir. Borç verenler açısından ise bir firmanın ya da ülkenin derecelendirilmesi sadece kredi verme kararı için değil, aynı zamanda fiyatlandırma, izleme ve karşılık ayırma gibi konularda da önemlidir. Ancak derecelendirme notlarının belirli bir takvim çerçevesinde ilan ediliyor olması kredi derecelendirme kuruluşlarının riskin nasıl değiştiğini değerlendirmekonusundaki performanslarını tartışma konusu haline getirmiş, özellikle 2008 küresel finansal krizinden sonra kredi notlarının mevcut kredi riskini ortaya koymakta yeterli olamadığ görüşü tartışılmaya başlanmıştır. Akademik çevrelerde ve uluslararası kuruluşlar arasındaki bir diğer tartışma konusu da kredi notlarının finansal işlemlerde geniş bir çerçevede kullanılmasının bağımlılık yarattığ iddiası olmuştur. Tüm bu gelişmeler kredi riski göstergesi olarak kredi notlarına alternatif arayışlarının hızlanmasında etkili olmuş ve kredi türevleri ön plana çıkmaya başlamıştır.

Kredi türevleri, kredi riskine sahip bir finansal aracın getirisinin önceden üzerinde anlaşılan seviyenin altına düşme riskine karşı, o varlığın kendisine dokunmaksızın, söz konusu riski başkasına transfer etmeye yarayan ve diğer bir finansal üründen türetilen finansal sözleşmelerdir(Kunt ve Taş, 2008). Bunların arasında finansal piyasalarda ve kurumlarda en fazla benimsenenlerden birisikredi temerrüt takasları olmuştur.

Kredi temerrüt takası; en dar tanımıyla kredi riskini etkin bir biçimde yönetme amacı taşıyan bir çeşit finansal sigorta sözleşmesi, en geniş tanımıyla ise herhangi bir finansal kredinin geri ödenmeme riskine karşı alacaklı tarafın parasını koruma altına alan, bunu da belirli bir bedel (prim) karşıllğında gerçekleştiren kredi türev ürününe verilen isimdir (Kunt ve Taş, 2008).Aslında CDS'ler maruz kalınan temerrüt riskinin bir başkasına transfer ediilmesini sağlayan sigorta özelliklerine sahip finansal araçlardır. Ancak sigorta regülasyonlarının gerektirdiği rezerv zorunlulukları"swap" (takas) teriminin tercih edilmesine sebep olmaktadır. CDS sözleşmesi satın alarak temerrüt riskine karşı kendini koruma altına alan borç veren, sigorta poliçesine benzer biçimde prim ödemesi yapmaktadır. Kredinin tam ve zamanında geri ödenmemesi durumunda ise borç verenin kayıpları CDS sözleşmesi satıcısı tarafından karşıllanmaktadır.

CDS'lerin diğer kredi risk göstergelerine göre başlıca faydası primlerin günlük bazdaayarlanıyor olması ve mevcut koşulları yansıtmasıdır. Fiyatlar arz ve talebi içerecek şekilde güncellenmekte ve piyasada ortaya çıkan yeni durumlar hızla CDS primlerine yansımaktadır (Hull, 2008).Bu konuda yapılan araştırmalardan birinde Flannery, Houston ve Partnoy (2010) ABD'de 2007 ve 2008 yılları arasında düşük faizli ipotekli krediler ile ilgili bilgileri CDS'lerin yansıtmasına karşın kredi notlarının nispeten değişmeden kaldığını ortaya koymuşlar ve CDS'lerin bilgiyi kredi derecelendirmelerinden daha hılı ve doğru bir şekilde yansıttığı sonucuna ulaşmışlardır.Norden ve Weber'e (2009) göre de CDS'lerintemerrüt 
riskini diğer risklerden ayırmak suretiyle yalın olarak yansitıyor olması, kredi riskinin belirlenmesinde ve fiyatlandırılmasında uygun bir gösterge olarak kabul edilmesini sağlamaktadır.

Bir ülkeye yapılması öngörülen dolaylı veya dolaysız yatırımların karar süreçlerinde de ülke riskinin uygun bir araçla doğru olarak değerlendirilebilmesi önemlidir. Ülkelerin kredi riski ölçümünün ve yatırımcıların ilgili ülkeye yönelik risk algısının başlıca belirleyicilerinden birisi CDS'lerdir. Ülkedeki ekonomik, siyasi ve sosyal gelişmeler ile güvenilirlik ve şeffaflık gibi çeşitli durumlara ilişkin olumlu veya olumsuz bilgiler CDS primlerine yansımaktadır.CDS primlerindeki değişimler ülkedeki ekonomik birimlerin kredi maliyetlerindeki gelişmeleri yansıtmakta ve ülkenin ekonomik performansına ilişkin önemli bir gösterge oluşturmaktadır.Ortaya çıkacak ekonomik ve finansal göstergelerdeki bozulmalar ya da politik istikrarsızlıklar risk primininartmasına yol açarakuluslararası yatırımcıların hem borçlanma araçları hem de hisse senedi piyasalarından çıkış yönünde hareket etmesine ve piyasalarda likidite sorunlarının ortaya çıkmasına neden olabilmektedir(Kılcı, 2017).

Ülke riskinin hisse senedi piyasasıüzerindeki etkileri finans literatüründeki tartışma alanlarındandır. Yatırımcılar, bir ülkenin ekonomik, politik ve finansal koşullarından doğrudan ya da dolaylı olarak etkilenmektedirler (Bolak, 1991).Ülke riskinin artması yatırımcının kaynaklarını daha güvendiği bir araca veya ülkeye yönlendimesine sebep olabilmektedir. Risk algısındaki değişmenin etkisini en hızlı gösterdiği alanlardan birisi hisse senedi piyasalarıdır.

Etkin bir hisse senedi piyasası firmaların temerrüt olasılığı ile ilgili bilgileri zamanında ve tam olarak içermelidir. Kredi ve hisse senedi piyasalarında oluşacak bu bilgiler arasındaki bağlantıyı irdeleyen Merton (1974), tahvil ve hisse senedi fiyatlarını temerrüt riski ile ilişkilendirmiş, yüksek hisse senedi fiyatlarının beraberinde düşük temerrüt riski getirmesi gerektiğini belirtmiştir. Merton'a (1974) göre, bir kredi türevinin değeri, referans varlığın gelecekte bir noktada temerrüt riskine maruz kalma olasılığg ile bağlantılı olmalıdır. Temerrüt riski ile hisse senedi fiyatları arasındaki ilişki geçerli değilse arbitraj yanlış fiyatlamayı ortadan kaldıracaktır. Ancak bu modelde ülkenin kredi bilgileri ile hisse senetleri piyasası arasındaki bağlantı açık değildir. Chan-Lau ve Kim (2004) Merton'un modelini genişletmişler, örneğin ülkenin ödeme gücü azalıp sermaye gereksinimi arttığında hisse senedi piyasası endeks değerlerinin düşeceğini ve CDS primlerinin artacağını ifade etmişlerdir. Borsa İstanbul içerisinde yer alan bankalara yapılan yatırımlar da bundan bağımsız değildir. Aynı zamanda CDS primlerinin de belirleyicileri olan politik, ekonomik ve finansal koşulların bankacılık endeksi içerisinde yer alan şirketlere yapılan yatırımların miktarı ve süresi konusunda etkili olması beklenir (Kendirli ve Çankaya, 2016).

Bir ülkedeki ekonomik sorunların etkilerinin ilk ve en fazla hissedildiği sektörleden birisi bankacılıktır. Ülke temerrüt riski ile bankacılık sistemi arasındaki ilişki 2007 yılının ortalarından itibaren ortaya çıkan finansal kriz ile birlikte üzerinde çok daha fazla çalışma yapılan konulardan birisi haline gelmiştir.

Uluslararası Ödemeler Bankası (BIS/2011), ülke riskinin finansal kurumlar üzerinde çeşitli kanallardan etkili olabileceğini belirtmektedir. Bunlardan birisi bankaların bilanço aktiflerinde tuttukları ülke borçlanma araçlarıdır. Bolton ve Jeanne (2011); Avrupa Birliği ülkelerinde Mart 2010 itibarıla ortalama olarak devlet borçlarının yaklaşık\%30'unun 
bankacıllk sektörü tarafindan tutulduğunu, İspanya ve Almanya için bu oranın yaklaşı\%50 olduğunu belirmektedirler. Angeloni ve Wolff (2012), Yunanistan, İrlanda, İtalya, Portekiz ve İspanya'nın ülke temerrüt riskine maruz kalmalarının banka hisse senetleri üzerine etkilerini araştırmışlardır. Sonuçlar Temmuz - Ekim 2011 döneminde Yunanistan, Ekim - Aralık döneminde ise İtalya ve İrlanda'nın maruz kaldığı ülke temerrüt riskinin banka hisse senetlerinin performansları üzerinde etkili olduğunu göstermiş̧ir.

Diğer bir etki kanalı bankaların kredi teminatı olarak gösterdikleri bilanço aktiflerindeki devlet borçlanma araçlarına yöneliktir. Kiyotaki ve Moore (2005) ve Kaminsky vd. (2003) araştırmalarında bir piyasadaki olumsuz şokların diğer piyasalardaki menkul kıymetlerle dayalı teminat değerlerini veya nakit akışlarını nasıl etkileyebildiğini ortaya koymuşlardır. Correa vd.(2012) ise çalışmlarında Avrupa borç krizi sürecinde potansiyel olarak teminat sorunlarına işaret eden Avrupa bankalarının ABD para piyasası fonlarına ulaşmakta sorunlar yaşadıklarını ortaya koymuşlardır.

Bankacılık sisteminde ortaya çıkan bir şokun ülke temerrüt riski üzerinde önemli etkileri olması şaşırtıcı değildir. Elbette bunun tersi de geçerlidir. Ülke kredi temerrüt riski primleri de ülkenin bankacılık sistemine yönelik anlamlı kredi riski bilgileri içerebilir. Acharya vd. (2011)'ne göre ülke kredi riski ile bankacılık sektörü arasında iki yönlü güçlü nedensellik ilişkisi mevcuttur.

\subsection{Literatür}

Geçmiş dönemdeki araştırmalar daha çok kredi notu ilanlarının hisse senedi fiyatları, tahvil fiyatları veya her ikisi üzerindeki etkilerinin analiz edilmesine yoğunlaşmaktadır. Genel görüş, eğer kredi derecelendirmeleri piyasaya yeni bilgiler aktarıyorsa, derecelendirme sonrası fiyatların tepki vermesi gerektiği yönündedir. Öte yandan, kredi derecelendirmelerinin piyasada zaten bilinen bilgileri yansıtıyor olması da mümkündür. Bu durumda ise fiyatların derecelendirme sonrası tepki vermemesi beklenir. Bir diğer deyişle finansal piyasalar firmalarla ilgili haberlere sürekli duyarlılık gösterirken, kredi notlarına zaman zaman tepki vermektedirler (Loffler, 2003). Son dönemlerde ise bilim insanları CDS primleri ile finansal piyasalarda oluşan fiyatlar arasındaki ilişkiyi incelemeye başlamışlardır. Bu araştırmaların önemli bir bölümü özel sektör CDS primleri üzerinedir. Buna karşıı ülke kredi temerrüt takas primleri üzerine yapılan çalı̧̧malar da giderek artmaktadır. Dünya'da ve ülkemizde ilgili konuda yapılan çalışmaların bir kısmı aşağıda özetlenmiştir.

Tablo 1. Literatür Taramas1

\begin{tabular}{llll}
\hline Araştırmacılar & Değişkenler / Veriler & Dönem & Sonuç \\
\hline Byström, 2005 & Avrupa iTraxx CDS ve hisse & $2004-2005$ & Araşırmaya konu tüm iTraxx \\
& senedi piyasaları & & endekslerinde pozitif otokorelasyon \\
& & mevcuttur. iTraxx CDS endeksi ile hisse \\
& & senedi fiyatları ve hisse senedi getirileri \\
& & & arasında yakın bir bağlantı bulunmaktadır. \\
& & CDS piyasas firmaya özel bilgiler \\
& & aktarmada etkilidir. Hisse senedi \\
& & getirisindeki oynaklıklar iTraxx CDS \\
& & endeks değerleri ile anlamlı bir şekilde \\
& & ilişkilidir.
\end{tabular}


Yapraklı ve

Güngör, 2007

ICRG ekonomik, finansal ve politik risk primleri ile İMKB 100 endeks değerleri

Fung vd.,2008

ABD hisse senedi ve kredi temerrüt takası piyasaları

Chanve Zhang, Çin, Japonya, Güney Kore, 2009

Norden ve

Weber 2009

Coronado ve

Lazcano, 2011

Sekiz Avrupa ülkesinin CDS primleri ve hisse senedi piyasalar1.

Balı ve Yılmaz, İMKB 100 Endeksi ile ülke 2012

Corzo vd.,2012 On üç Avrupa ülkesinin CDS primleri, devlet tahvilleri ve hisse senedi piyasaları.

Hanc1, 2014

Türkiye CDS dağılımları ile BİST-100 getirileri

Türkiye, Arjantin, Brezilya,

Yenice ve

Hazar, 2015
1986-2006

Ülke risk primleri ile hisse senedi fiyatları arasında uzun dönemli bir ilişki vardır. Ekonomik riskten ve siyasi riskten hisse senedi fiyatlarına doğru bir nedensellik bulunmakta. Finansal risk ve hisse senedi fiyatları arasında nedensellik ilişkisi görülmemektedir.

2001-2007 Hisse senetleri ve CDS'ler arasındaki ilişki ilgili varlığın kredi kalitesine bağlı. Hisse senedi piyasasında fiyatlandırma sürecinde CDS endeksi yatırımın derecesini yönlendirmektedir.

2001-2007 Beş ülkede CDS primleri hisse senedi piyasasına öncülük etmekte ve hisse senedi endeksleri ile CDS primleri arasında güçlü bir negatif korelasyon bulunmaktadir.

2000-2002 Hisse senedi değișkeni CDS primleri ve tahvil fiyatlarında değişimlere neden olmakta. CDS piyasalarındaki hareketlerhisse senedi piyasalarındaki hareketlere tahvil piyasasından daha fazla duyarlidir.

2007-2010 İspaya, Portekiz, İtalya, Fransa, İrlanda, İngiltere, Yunanistan ve Almanya'da CDS'ler ile hisse senetleri fiyatları arasında negatif ve güçlü bir korelasyon bulunmaktadır.

2002-2012 İMKB 100 Endeksi ile kredi temerrüt takası marjları arasında ters yönlü bir ilişki mevcuttur.

2008-2011 Algılanan kredi riskinin yüksek olduğu ekonomilerde ülke CDS'ler daha güçlü bir rol oynamakta. Özellikle 2010 y1lında ülke CDS'lerinin rolünün yüksek olduğuna dair bulgular mevcuttur. 2007-2009 yilları arasında İspanyol CDS'leri fiyatların oluşumuna öncülük ederken bu rolü 2011'de İtalyan ve Fransız CDS'leri devralmaktadir.

2008-2012 CDS baz puanı ile BIST-100 getirileri arasında negatif yönlü bir ilişki mevcuttur. Değişkenler arasındaki oynaklık çok yüksek, şoklar dirençli ve ortalamaya geri dönüşler zaman almaktadır.

2009-2014 Ülkelerin dördünde önemli kabul edilebilecek düzeyde ilişki bulunmaktadır. Türkiye'nin CDS primi ile borsa endeksi arasında orta düzeyde bir hassasiyet mevcuttur. CDS primleri gelişmekte olan ve yatırım potansiyeli taşıyan ülkelere yapılan yatırımlarda dikkate alınmaktadır. 
Eren ve Başar, Kredi temerrüt takas işlemleri 2016 ve BİST-100 Endeksi

Kayhan vd.,2016

Değirmenci ve Pabucçu, 2016

Kadooğlu vd.,2016

Başarır ve Keten, 2016

Shear vd.,2017 BİST-100 Endeksi ve ABD ile Avrupa'daki CDS piyasaları

2009-2015 vrupa'daki CDS piyasalan

Türkiye'ye ait 5 yıllık CDS primleri ile Borsa İstanbul Hisse Senedi değerleri

Almanya, Brezilya, Endonezya, Fransa, İrlanda, İtalya, Malezya, Rusya, Şili ve Türkiye CDS primleri ile borsa endeksleri.

JP Morgan Gelişen Piyasalar Hisse Senedi Endeksi (EMBI) ile endekse dahi 12 ülkenin CDS primleri.

Ülke CDS ve Karachi Menkul Kiymetler Borsası KSE100 Endeksi

Jeanneret, 2017 Avrupa ülkeleri temerrüt riskleri ve ilgili ülkeler ile ABD hisse senedi piyasaları

Apergis, N. (2017)

Fonseca ve Gottschalk, 2018

Gün, 2018

Sovbetov ve Saka, 2018

2005-2014

2010-2015

$1991-2013$

ulke kredi temerrüt takas marjları ve hisse senedi endeksleri

BIST-100 endeksi ve CDS fiyatları
Kredi temerrüt takas işlemleri kısa vadede hisse senedi fiyatlarını olumsuz yönde etkilerken uzun vadede etkisi bulunmamaktadır.

Türkiye ekonomisinde CDS primlerindeki göreli değişmeler BİST100'ü etkilemektedir. ABD ve Euro alanı ile göreli CDS primi farklılıkları ve BİST100 endeksi arasında ilişki mevcut. Prim farkının açılması durumunda hisse senedi endeksi düşmektedir.

2009-2014 CDS primleri ile hisse senetleri arasında ters yönlü bir ilişki söz konusudur.

CDS primleri ile borsa endeks kapanışları arasında İrlanda en hassas ilişkiye sahipken Endonezya'da bu durumun tam tersi mevcuttur. Türkiye açısındanise ilişsi zayıftır.

2010-2016 Kisa dönemde CDS primleri ile EMBI arasında çift yönlü bir nedensellik ilişkisi mevcuttur. Uzun dönemde ise nedensellik ilişkisi bulunmamaktadır.

2004-2012 Ülke CDS göstergeleri ile KSE100 Endeksi arasında aşamalı olarak artan negatif ve istatistiksel olarak anlamlı bir ilişki ve her iki piyasa arasındaki çift yönlü nedensellik ilişkisi bulunmaktadır.

Avrupa'daki ülke temerrüt riskleri Avrupa ve ABD hisse senedi piyasalarını ekonomik yavaşlama tehdidiyle güçlü bir şekilde etkileyerek hisse senedi fiyatlarını düşürmekte ve oynaklığı artırmaktadır.

2005-2015 Yunanistan borç krizi döneminde ve uygulanan kurtarma ve tasarruf programlarının resmi olarak kabul edilmesinin ardından geçen sürede ülke CDS'i hisse fiyatları üzerinde etkilidir.

2007-2010 Endeks seviyesinde hisse senedi ve CDS piyasaları arasındaki bağlantı düzeyi düşüktür. Firma seviyesinde hisse senedi getirileri CDS primleri üzerinde etkilidir.

2010-2017 Ülke kredi temerrüt takas marjları ile hisse senedi fiyatları arasında negatif korelasyon mevcuttur. Hisse senedi endekslerinde CDS marjlarına yönelik güçlü nedensellik ilişkisi bulunmaktadır.
BIST-100 endeksi ve Türkiye'nin CDS fiyatları döviz kurlarındaki oynaklıklara ve politik alandaki belirsizliklere aşırı duyarlıdır. 


\begin{tabular}{|c|c|c|c|}
\hline $\begin{array}{l}\text { Mataev ve } \\
\text { Marinova,2019 }\end{array}$ & $\begin{array}{l}\text { MarkitiTraxx Europe ve ilgili } \\
\text { endekse dahil } 109 \text { firmanın } \\
\text { hisse senetleri }\end{array}$ & $2012-2016$ & $\begin{array}{l}83 \text { firmada CDS'ler ile hisse senedi } \\
\text { fiyatları arasında uzun dönemli ilişki } \\
\text { mevcuttur. }\end{array}$ \\
\hline
\end{tabular}

\section{VERILER VE YÖNTEM}

AraştırmaOcak/2014 ileHaziran/2019 arasındaki dönemi kapsamaktadır. Bloomberg ve Garanti Bankasından (paragaranti) alınan veri seti günlük bazda olupbeş yıl vadeli ülke kredi temerrüt takası primleri(TCDS5) ile BİST Banka Endeksi (XBANK) ve bu endeks içinde yer alan Akbank (AKBKN), Albaraka Türk (ALBRK), Denizbank (DENIZ), Garanti Bankası (GARAN), Halk Bankası (HALK), ICBC Turkey (ICBCT), İş Bankası (ISCTR), QNB Finansbank (QNBFB), Şekerbank (SKBNK), Türkiye Sınai Kalkınma Bankası (TSKB), Vakıfbak (VAKBN) ve Yapı Kredi Bankası (YKBNK) kapanış değerlerini içermektedir. Çalışmada 14 değişkenin her biri için 1.365 adet gözlem yapılmıştır. Değişkenlere ilişkin özet tanımlayıcı isatistikler Tablo 2'de verilmiştir.

Tablo 2. Tanımlayıcı İstatistikler

\begin{tabular}{lrrrrrrrr}
\hline Değişkenler & Gözlem & Minimum & Maksimum & Ortalama & Medyan & Çarpıklık & Basıklık & $\begin{array}{c}\text { Std. } \\
\text { Sapma }\end{array}$ \\
\hline TCDS5 & 1365 & 133,47 & 576,62 & 253,22 & 239,67 & 1,43 & 2,19 & 77,33 \\
XBANK & 1365 & $93.563,62$ & $192.443,36$ & $140.371,31$ & $136.923,77$ & 0,33 & $-0,56$ & $20.317,90$ \\
AKBNK & 1365 & 4,67 & 9,33 & 7,27 & 7,45 & $-0,42$ & $-0,61$ & 0,92 \\
ALBRK & 1365 & 1,07 & 2,12 & 1,38 & 1,36 & 0,58 & 0,76 & 0,16 \\
DENIZ & 1365 & 1,68 & 21,72 & 4,26 & 2,95 & 2,42 & 5,20 & 3,86 \\
GARAN & 1365 & 5,68 & 12,36 & 8,33 & 8,15 & 0,59 & 0,01 & 1,31 \\
HALK & 1365 & 4,94 & 16,78 & 10,66 & 10,43 & 0,14 & $-0,88$ & 2,80 \\
ICBCT & 1365 & 0,65 & 11,27 & 2,69 & 1,64 & 1,45 & 2,11 & 1,91 \\
ISCTR & 1365 & 3,81 & 8,22 & 5,44 & 5,28 & 0,49 & $-0,84$ & 1,08 \\
QNBFB & 1365 & 1,35 & 10,40 & 4,29 & 4,50 & 0,21 & $-0,36$ & 1,84 \\
SKBNK & 1365 & 0,84 & 2,19 & 1,47 & 1,48 & 0,05 & $-1,10$ & 0,29 \\
TSKB & 1365 & 0,65 & 1,41 & 0,99 & 0,98 & 0,21 & $-0,58$ & 0,16 \\
VAKBN & 1365 & 0,76 & 7,57 & 4,81 & 4,54 & 0,74 & $-0,11$ & 1,03 \\
YKBNK & 1365 & 1,53 & 5,25 & 3,13 & 2,91 & 0,30 & $-1,01$ & 0,95 \\
\hline
\end{tabular}

Finans araştırmalarında kullanılan başlıca veri türlerinden birisi zaman serileridir. Kullanılan serilerin durağan olduğu varsayımı ise zaman serilerine dayalı olarak gerçekleştirilen çalışmaların temel varsayımlarındandır. Bu kapsamda ilk olarak zaman serilerinin durağanlığıDickey-Fuller (DF) birim kök testi ile sınanmıştır.

DF testi zaman serisi değişkenlerinin otoregressif süreçle ifade edilip edilemeyeceğini göstermekte olup, test sonucunda hata teriminde otokorelasyon bulunması halinde zaman serileri birinci dereceden otoregressif süreçle ifade edilememektedir (Göktaş, 2005). DF testinde en küçük kareler yöntemi aracılığıyla $\gamma=0$ hipotezi için birim kök testi uygulanmakta ve $t$ istatistiği bulgularına bağlı olarak karar verilmektedir.

Durağan olmayan iki zaman serisinin aynı derecede entegre olmaları durumunda da aralarında bir eşbütünleşme olması mümkündür. İki zaman serisinin aynı derecede durağan 
olması her birindeki trendin diğerini götürmesi suretiyle trend faktöründen arınmış bir ilişki sağlamaktadır.

Durağanlık sınamaları Dickey-Fuller (DF) testinin geliştirilmiş yöntemi olan ve literatürde sıklıkla kullanılan ADF Birim Kök Testi ile gerçekleştirilmiş̧ir.

$$
\begin{gathered}
\Delta \mathrm{X}_{\mathrm{t}}=\beta_{0}+\beta_{1} \mathrm{X}_{\mathrm{t}-1}+\sum_{\mathrm{i}=1}^{\mathrm{k}} \lambda_{\mathrm{i}} \Delta \mathrm{X}_{\mathrm{t}-1}+u_{\mathrm{t}}(1) \\
\Delta \mathrm{X}_{\mathrm{t}}=\beta_{0}\left|\beta_{1} \mathrm{X}_{\mathrm{t}-1}\right| \beta_{2} \text { trend } \sum_{\mathrm{i}=1}^{\mathrm{k}} \lambda_{\mathrm{j}} \Delta \mathrm{X}_{\mathrm{t}-1} \mid u_{\mathrm{t}}(2)
\end{gathered}
$$

Eşitliklerde $(\mathrm{X})$ analizedilen seriyi, $(\Delta)$ fark operatörünü, $(\mathrm{k})$ denklemdeki bağımlı değişkene ait gecikmeleri, $(\beta)$ ve $(\lambda)$ parametreleri, (trend) doğrusal zaman trendini ve $\left(u_{\sharp}\right)$ hata terimini göstermektedir.

İkinci aşamada bütünleşik zaman serileri arasında uzun dönemli bir ilişkinin varlığını belirleyebilmek amacıyla eşbütünleşme analizi yapılmıştır. Eşbütünleşme uzun dönem serilerinde fark alınması nedeniyle ortaya çıkabilen bilgi kaybının ve çözümsüzlügün engellenmesini sağlayan bir yaklaşım olarak kabul edilmektedir. Bu varsayım altında zaman serilerinin düzey değerleri arasındaki regresyon sahte olmayıp anlamlıdır. Değiş̧kenlerin arasındaki eşbütünleşme ilişkisinin belirlenmesi, uzun dönemligerçek bir ilişki olduğunu göstermekte, bir diğer deyişle değiş̧kenlerin uzun dönemde birlikte hareket ettiğini ortaya koymaktadır.

Uzun dönemli ilişkiyi belirleyebilmekiçinJohansen ve Juselius tarafindan $(1988,1990)$ geliştirilen Johansen Eşbütünleşme testi uygulanmıştır. Bu yöntem serilerin uzun dönemli ilişkilerinin ortaya çıkarılmasında sıklıkla kullanılmaktaolup VAR (Vector Auto Regression) analizine dayanmaktadır (Tarıve Yıldırım, 2009). VAR modelinde içsel-dışsal ayrımı yok olmaktadır. Bağımlı değişkenin gecikmeli değerlerinin açıklayıcı değişken olarak modele girmesiyle geleceğe dönük anlamlı tahminler ortaya konulabilmektedir.

Johensen Eşbütünleşme Testi ile aralarında ilişki olduğu tespit edilen serilerin etki derecelerini belirleyebilmek amacıylaPedroni’ye ait (2000)Tam Değiştirilmiş En Küçük Kareler (FMOLS) analizi yöntemi uygulanmıştır. FMOLS' un en büyük avantajı değişken katsayılarını hesaplamasının yanı sıra otokorelasyon, değişken varyans ve içsellik gibi sorunlardan kaynaklanabilecek bozulmaları düzelterek sapmasız sonuçlar verebilmesidir. FMOLS'un endojenite ve oto korelasyonu düzeltmek suretiyle tutarlı ve etkin uzun dönem tahminler sağlayabildiği kabul edilmektedir.Bu yöntemle uzun dönemli ilişki katsayıları tespit edilerek Ülke Temerrüt Takası'nın BİST Banka Endeksi ve endekste yer alan her bir hisse senedi değerine ne kadar etki ettiğinin belirlenmesi ve kıyaslanması mümkün hale getirilmiştir.

Araştırma kapsamındaki serilerin durağan hale getirilmesini teminen uygulanan fark işlemi, serilerin uzun dönem bilgilerinde kayıpların ortayaçıkmasına sebep olabilmektedir. Bu kapsamda kısa ve uzun dönem ilişkisi arasındaki dengesizliğin giderilerek kısa dönemli ilişkileri ortaya koymak amacıyla hata düzeltme modeli (VECM) kurulmuştur. Hata düzeltme modelinin faydalarından birisi kısa ve uzun dönemli nedenselliklerin ortaya konulabilmesi ve değişkenler arasındaki dengesizliğin belirlenip düzeltilmesinin sağlanabilmesidir (Enders, 1995). 




Hata düzeltme modeli sonuçlarına göre katsayıların istatistiki olarak anlamlı ve negatif işaretli olması, kısa dönemdeki durumun ne kadarının uzun dönemle karşılanabileceğini ortaya koymaktadır.

Son aşamada ise Granger nedensellik analizi yapılmıştır. 1969 yılında Granger tarafından geliştirilen nedensellik kuramına göre iki değişken arasındaki nedensellik ilişkisi, değişkenlerden birinin mevcut dönemdeki değeri diğer değişkenlere ait gecikmeli değerlerin bir katkı sağlayıp sağlamadıklarına bağlı olarak açıklanır. Diğer bir ifadeyle (Y) değişkeninin $(t)$ zamanındaki değerini açıklamak için oluşturulan modelin açıklama gücü $(\mathrm{X})$ değişkeninin gecikmeli değerleri içerildiğinde artmakta ise; X, Y'nin Granger nedenidir şeklinde açıklanır ve nedensellik ilişkisi $\mathrm{X} \rightarrow \mathrm{Y}$ şeklinde gösterilir (Gujarati ve Porter, 2009). Granger Nedensellik testi aşağıdaki denklemler yardımı ile gerçekleştirilmektedir(Göktaş Yılmaz, 2005).

$$
\begin{aligned}
& Y_{t}=\sum_{i=1}^{m} \alpha_{t} Y_{t-t}+\sum_{i=1}^{m} \beta_{f} X_{t-f}+u_{1 t} \\
& X_{t}=\sum_{i=1}^{m} e_{t} X_{t-t}+\sum_{f=1}^{m} \gamma_{f} Y_{t-f}+u_{2 t}
\end{aligned}
$$

\section{AMPIRIKK BULGULAR}

ADF Birim Kök Testi ile yapılan sınamalar Akbank ve Albaraka Türk serilerinin düzey durağan, diğer tüm serilerin ise birinci farkları alındığında durağan olduklarını ortaya koymuştur. Durağanlık seviyeleri arasındaki farklılıktan dolayı Akbank ve Albaraka Türk serileri modelden çıkartılmıştır. Söz konusu iki değişken dışındakilerin birinci farkları alındıktan sonra yapılan testte değerlerin 0,05 düzeyinde anlamlı oldukları görüldüğünden sıfir hipotezi reddedilmiş ve bu serilerin birinci düzeyde durağan oldukları kabul edilmiştir.

Tablo 3. ADF Birim Kök Testi

\begin{tabular}{lcc}
\hline Değişkenler & Seviyede & Birinci Fark \\
\hline TCDS5 & 0,575 & $0,000^{*}$ \\
XBANK & 0,138 & $0,000^{*}$ \\
AKBNK & $0,0360^{*}$ & - \\
ALBRK & $0,0170^{*}$ & - \\
DENIZ & 0,969 & $0,000^{*}$ \\
GARAN & 0,070 & $0,000^{*}$ \\
HALK & 0,527 & $0,000^{*}$ \\
ICBCT & 0,165 & $0,000^{*}$ \\
ISCTR & 0,271 & $0,000^{*}$ \\
QNBFB & 0,365 & $0,000^{*}$ \\
SKBNK & 0,380 & $0,000^{*}$ \\
TSKB & 0,252 & $0,000^{*}$ \\
VAKBN & 0,285 & $0,000^{*}$ \\
YKBNK & 0,688 & $0,000^{*}$ \\
\hline
\end{tabular}

* \%5 düzeyinde anlamlı 
Analizin ikinci aşamasında uzun dönemli ilişkiyi tespit edebilmek amacıyla VAR analizine dayalı JohansenEşbütünleşme testi uygulanmıştır. Sınama sonrası Ülke Temerrüt Takasının uzun dönemde etki ettiği serilerin sırasıyla BİST Banka Endeksi, Garanti Bankası, ICBC Turkey, QNB Finansbank ve Vakıfbank olduğu görülmüştür. Yapılan Trace (İz) ve Maximum Eigenvalue (Maksimum Özdeğer) testlerinden elde edilen bulgular birbirleriyle örtüşmektedir. Normalize edilmiş matris değerler incelendiğinde söz konusu ilişkilerin tamamının pozitif yönde istatistiki açıdan anlamlı olduğu görülmüştür.

Tablo 4. Eşbütünleşme Testi

\begin{tabular}{lccc}
\hline Değişkenler & $\begin{array}{c}\text { Eşbütünleşme Katsayısı (Trace / } \\
\text { Max-Eigen) }\end{array}$ & Anlamlılık Değeri & $\begin{array}{c}\text { Normalize Edilmiş } \\
\text { Matris Değeri }\end{array}$ \\
\hline XBANK & $32,58994 / 27,20624$ & $0,0063 / 0,0030$ & 310,6052 \\
GARAN & $26,62732 / 21,35442$ & $0,0402 / 0,0256$ & 0,018615 \\
ICBCT & $26,72113 / 20,88752$ & $0,0392 / 0,0301$ & 0,004978 \\
QNBFB & $6,420713^{*} / 6,420713^{*}$ & $0,0113 / 0,0113$ & 0,000551 \\
VAKBN & $39,85795 / 35,73044$ & $0,0005 / 0,0001$ & 0,015702 \\
\hline
\end{tabular}

* "En çok bir eşbütünleşme vardır.” hipotezi reddedilmiş ve iki eşbütünleşme olduğu tespit eilmiştir.

Johenseneşbütünleşme testi sonucu aralarında ilişki olduğu tespit edilen serilerin etki derecelerinin tespit edilebilmesi için FMOLS analizi yapılarak uzun dönemli ilişki katsayıları belirlenmiştir. Bu yöntemle Ülke Temerrüt TakasınınBankacılık Endeksi ile her bir hisse senedi değerine ne kadar etki ettiği görülmüş ve kıyaslama yapılabilmesi mümkün hale gelmiştir. Analiz bulguları Ülke Temerrüt Takasında yaşanabilecek olan bir birimlik artışın bankacılık endeksini yaklaşık 283 birim düşürebileceğini ortaya koymaktadır.

Tablo 5. FMOLS Testi

\begin{tabular}{lcr}
\hline Değişkenler & Katsayı & Anlamlılık Değeri \\
\hline XBANK & $-282,7798$ & $0,0000^{*}$ \\
GARAN & $-0,016809$ & $0,0000^{*}$ \\
ICBCT & $-0,002623$ & $0,0461^{*}$ \\
QNBFB & $-0,00132$ & 0,1993 \\
VAKBN & $-0,014209$ & $0,0000^{*}$ \\
\hline
\end{tabular}

Bir sonraki aşamada Johansen Testi sonucu eşbütünleşme bulunan seriler için kısa dönemli ilişkilerin ortaya konulabilmesini teminenHata Düzeltme Modeli (VECM) kurulmuştur. Aşağıdaki tabloda söz konusu model değerleri görülmektedir. Katsayının (CointEq1 değerinin) negatif hesaplanması kısa dönemli etkiyi göstermekte ve söz konusu değişkende yaşanacak olan bir şokun (ani bir değişmenin) bir sonraki dönemde giderilme oranını ortaya koymaktadır. 
Tablo 6. VECM Testi

\begin{tabular}{lc}
\hline Değişkenler & Katsayı \\
\hline XBANK & $-0,01653$ \\
GARAN & $-0,02246$ \\
ICBCT & $-0,01783$ \\
QNBFB & $-0,01678$ \\
VAKBN & $-0,01384$ \\
\hline
\end{tabular}

Son aşamada ise GrangerNedensellik Analizi yapılmıştır. Bulgular Ülke Temerrüt Takası ile Garanti Bankasının iki yönlü nedensellik ilişkisine sahip olduğu göstermektedir. Ülke Temerrüt Takası ile tek yönlü Grangernedenselliği bulunan değişkenler Vakıfbank, Yapı Kredi, Türkiye Sinai Kalkınma Bankası, İş Bankası ve BİST Banka Endeksidir. Halkbank ise Ülke Temerrüt Takası'nınGranger nedenidir.

Tablo 7. Granger Nedensellik Testi

\begin{tabular}{llr}
\hline İlişki Hipotezi $\left(\boldsymbol{h}_{0}\right)$ & $\begin{array}{l}\text { Anlamlılık } \\
\text { Değeri }\end{array}$ & Karar \\
\hline TCDS5 $\rightarrow$ XBANK & $0,0194^{*}$ & Red \\
TCDS5 $\rightarrow$ GARAN & $0,0088^{*}$ & Red \\
TCDS5 $\rightarrow$ ICBCT & 0,2208 & Kabul \\
TCDS5 $\rightarrow$ QNBFB & 0,2104 & Kabul \\
TCDS5 $\rightarrow$ VAKBN & $0,0025^{*}$ & Red \\
TCDS5 $\rightarrow$ YKBNK & $0,0129^{*}$ & Red \\
TCDS5 $\rightarrow$ TSKB & $0,0006^{*}$ & Red \\
TCDS5 $\rightarrow$ ISCTR & $0,0331^{*}$ & Red \\
TCDS5 $\rightarrow$ HALK & 0,6423 & Kabul \\
XBANK $\rightarrow$ TCDS5 & 0,9668 & Kabul \\
GARAN $\rightarrow$ TCDS5 & $0,0455^{*}$ & Red \\
ICBCT $\rightarrow$ TCDS5 & 0,3096 & Kabul \\
QNBFB $\rightarrow$ TCDS5 & 0,5845 & Kabul \\
VAKBN $\rightarrow$ TCDS5 & 0,4067 & Kabul \\
YKBNK $\rightarrow$ TCDS5 & 0,1167 & Kabul \\
TSKB $\rightarrow$ TCDS5 & 0,4559 & Kabul \\
ISCTR $\rightarrow$ TCDS5 & 0,1429 & Kabul \\
HALK $\rightarrow$ TCDS5 & $0,0083^{*}$ & Red \\
\hline
\end{tabular}

\section{SONUÇ}

CDS bir ülke veya firma tarafından çıkarılan borçlanma araçlarına ait ödemelerin tam ve zamanında gerçekleşmemesi riskine karşı koruma sağlayan finansal türev ürünlerdir. Diğer taraftan CDS'ler ülkelerin kredi riskinin ölçümünün ve yatırımcıların ilgili ülkeye yönelik risk algısının başlıca belirleyicilerinden biri olarak kabul da edilmektedir. Risk algısındaki değişmenin etkisini en hızlı gösterdiği alanlardan bir diğeri hisse senedi piyasalarıdır. CDS primleri ile hisse senetleri piyasası arasındaki ilişkinin belirlenmesine yönelik dünyada ve ülkemizde çeşitli yöntemlerle birçok çalışma yapılmıştır. Buna karşın yerel literatürde banka 
hisse senetleri fiyatları ile ülke CDS primleri ilişkisi üzerine gerçekleştirilen bir araştırmaya rastlanılmamıştır.

Bankacılık sisteminde ortaya çıkan bir şokun ülke temerrüt riski üzerinde önemli etkileri olması şaşırtıcı değildir. Elbette bunun tersi de mümkündür ve ülke kredi temerrüt riski primleri ülkenin bankacılık sistemine yönelik anlamlı kredi riski bilgileri içerebilir. Bu kapsamda ülkemizin CDS primleri ile BİST Banka Fiyat Endeksi ve bankaların hisse senedi fiyatları arasındaki kısa ve uzun dönemli ilişki araştııılmış ve ülke riski algısının belirtilen piyasalar üzerindeki etkileri belirlenmeye çalışılmıştır. Veri seti günlük bazda olup beş yıl vadeli ülke kredi temerrüt takası primleri ile BİST Banka Endeksi ve bu endekse içinde yer alan bankalara ait hisse senetlerinin Ocak/2014 ile Haziran/2019 arasındaki borsa kapanış değerlerini içermektedir.

Çalışmada kullanılan zaman serilerinin durağanlığı Dickey-Fuller (DF) birim kök testi ile sınanmış ve Akbank ile Albaraka Türk serilerinin düzey durağan, diğer tüm serilerin ise birinci farkları alındığında durağan olduklarını görülmüştür. Durağanlık seviyelerinin farklı olmasından dolayı belirtilen iki bankaya ait seriler modelden çıarılmıştır.Ikinci aşamada bütünleşik zaman serileri arasındaki uzun dönemli anlamlı ilişkinin varlığını belirleyebilmek için VAR analizine dayalı JohansenEşbütünleşme testi uygulanmış ve Ülke Temerrüt Takasının uzun dönemde etki ettiği serilerin sırasıyla BİST Banka Endeksi, Garanti Bankası, ICBC Turkey, QNB Finansbank ve Vakıfbank olduğu belirlenmiş̧tir.Bir diğer ifadeyle ilgili değişkenler uzun dönemli denge ilişkisine sahiptir ve aralarında durağan ve doğrusal ilişki söz konususudur.

Aralarında ilişki olduğu tespit edilen serilerin etki analizi bulguları ise Ülke Temerrüt Takasında yaşanabilecek olan bir birimlik artışın bankacılık endeksini yaklaşık 283birim düşürebileceğini göstermektedir.Ülke CDS'lerinde bir birimlik değişikliğin banka hisse senedi değerlerine yaklaşık etkileri ise sırasıyla; Garanti Bankası: 0,017, ICBC Turkey: 0,003, QNB Finansbank: 0,001 ve Vakıfbank: 0,014 birim olacaktır. Kurulan Hata Düzeltme Modeli'nin bulguları ise değişkenlerde yaşanacak olan bir şokun bir sonraki dönemde giderilme oranlarının yaklaşık olarak; BİST Bankacılık Endeksinde 0,0165 banka hisse senetlerinde ise Garanti Bankasi: 0,022, ICBC Turkey: 0,018, QNB Finansbank: 0,017 ve Vakıfbank: 0,014 olduğunu ortaya koymaktadır.

Son aşamada ise Granger Nedensellik Analizi yapılmıştır. Bulgular Ülke Temerrüt Takası ile Garanti Bankasının iki yönlü nedensellik ilişkisine sahip olduğu göstermektedir. Ülke Temerrüt Takası ile tek yönlü Granger nedenselliği bulunan değişkenler; Vakıfbank, Yapı Kredi, Türkiye Sinai Kalkınma Bankası, İş Bankası ve BİST Banka Endeksidir. Halkbank'ın ise Ülke Temerrüt Takası'nınGranger nedenidir. Bir diğer ifadeyle Granger nedensellik test sonuçları, Ülke Temerrüt Takası primlerindeki değişimin Vakıfbank, Yapı Kredi, Türkiye Sinai Kalkınma Bankası, İş Bankası hisse senedi fiyatları ve BİST Banka Endeksi değerinde değişime sebep olduğunu göstermektedir. İlgili dönemde Ülke Temerrüt Takası primlerindeki değişim iseHalkbank hisse senedi fiyatlarındaki değişimi takip etmektedir.Ülke Temerrüt Takası primleri ile Garanti Bankası hisse senedi fiyatları arasında karşılıklı, yani birbirini besleyen iliş̧ki mevcuttur. 
Sonuç olarak, örneklem kapsamında Türkiye Kredi Temrrüt Takas primleri ile BİST Banka Endeksi ve bazı banka hisse senetleri eşbütünleşiktir. Ayrıca kısa dönemde Türkiye Kredi Temrrüt Takas primlerindeki göreli değişmeler BİST Banka Endeksi üzerinde ve bazı banka hisse senetleri üzerinde etkilidir. Ancak etkileşimin her dönemde geçerli olmayabileyeceği, çeşitli faktörlere bağlı olan risk algılarının değişebileceği göz önünde bulundurulmalidir.

\section{KAYNAKLAR}

Acharya, Viral V. -Drechsler, Itamar-Schnabl, Philipp (2011),“Apyrrhicvictory? Bank Bailouts And Sovereign Credit Risk', TheJournal of Finance, 69, pp.2689-2739.

Angeloni, Hiara-Wolff, Guntram B. (2012), Are Banks Affected by Their Holdings of Government Debt?, Bruegel Workıng Paper, 2012/07.

Apergis, Nicholas (2017), The Greek Debt Crisis - The Role of Sovereign CDS Spreads for Stock Prices: Evidence from the Athens Stock Exchange Over a 'Default' Period, Springer.

Aydın Kadooğlu, Gülden - Hazar, Adalet -Çütçü, İbrahim (2016), “ Kredi Temerrüt Takası İle Menkul Kıymet Borsaları Arasındaki İlişki: Gelişmiş ve Gelişmekte Olan Ülke Uygulamaları', Türk Sosyal Bilimler Araştırmaları Dergisi, 1(2), ss.1-21.

Balı, Selçuk - Yılmaz, Züleyha (2012), "Kredi Temerrüt Takası Marjları ile İMKB 100 Endeksi Arasındaki İlişki”, 16. Finans Sempozyumu Bildiriler Kitabı, Erzurum Atatürk Üniversitesi, İktisadi ve İdari Bilimler Fakültesi, 10-13 Ekim, Erzurum, ss.83104.

Bank for International Settlements(2011),Th eImpactof Sovereign Credit Risk on Bank Funding Conditions, Committee on the Global Financial System Papers, No: 43.

Başarır, Çağatay - Keten, Murat (2016), " Gelişmekte Olan Ülkelerin CDS Primleri ile Hisse Senetleri ve Döviz Kurları Arasındaki Kointegrasyon İlişkisi”, Mehmet Akif Ersoy Üniversitesi Sosyal Bilimler Enstitüsü Dergisi, 8(15), ss.369-380.

Bolak, Mehmet (1991),Sermaye Piyasası Menkul Kiymetler ve Portföy Analizi, Beta Yayınları, İstanbul.

Bolton, Patrick-Jeanne, Olivier (2011), “ Sovereign Default Risk and Bank Fragility in Financially Integrated Economies’, IMF Economic Review, 59 (2), pp.162 -194.

Byström, Hans (2005), F Prices: TheItraxx CDS Index Market, Department of Economics Working Paper No:24, Lund Universtiy - Sweden.

Chan, Kam C.- Fung, Hung-Gay-Zhang, Gaiyan (2009), “ On the Relationship Between Asian Sovereign Credit Default Swap Markets and Equity Markets', Journal of Asia Business Studies, 4(1), pp.3-12. 
Chan-Lau, Jorge A. - Kim, Yoon S. (2004), Equity Prices, Credit Default Swaps, and Bond Spreads in Emerging Markets, IMF Working Paper, WP/04/07.

Coronado, Maria -Corzo, Teresa -Lazcano, Laura (2011),“ A Case for Europe: The Relationship Between Sovereign CDS and Stock Indexes', Frontiers in Finance and Economics, 9(2), pp.32-63.

Corzo, M. Teresa -Gomez, Javier-Lazcano, Laura (2012),TheCo-movement of SovereignCreditDefaultSwaps, Sovereign Bond sand Stock Markets in Europe, http://ssrn.com/abstract=2000057, Erişim Tarihi: 23.04.2019.

Değirmenci, Nurdan -Pabuç̧u, Hakan (2016), Risk Primi ile BİST-100 Etkileşiminin İncelenmesi, 17.Uluslararası Ekonometri, Yöneylem Araştırması ve İstatistik Sempozyumu Bildiriler Kitabı, Cumhuriyet Üniversitesi Ekonometri Bölümü, 2-4 Haziran, Sivas, ss.101-102.

Demirgüç-Kunt, Asl1 -Huizingab, Harry (2013), “Are Banks too Big to Fail or too Big to Save? International Evidence from Equity Prices and CDS Spreads, Journal of Bankingand Finance, 37(3), pp.875-894.

Enders, Walter (1995),Applied Econometric Time Series, John Wiley\&Sons, Inc., New York

Eren, Murat - Başar, Selim (2016), "Effects Of Credit Default Swaps (CDS) on BIST-100 Index”, Ecoforum, 5 (Special Issue), pp.123-129.

Flannery, Mark J. - Houston, Joel F. -Partnoy, Frank (2010),Credit Default Swap Spreads as Viable Substitutes for Credit Ratings, University of Pennsylvania Legal Studies Research Paper Series Research Paper No: 10-31.

Fonseca, José Da -Gottschalk, Katrin (2018),TheCo-Movement of CreditDefault Swap Spreads, Equity Returns and Volatility: Evidence from Asia-Pacific Markets, International Review of Finance, https://doi.org/10.1111/irfi.12237. (Erişim Tarihi: 23.04.2019)

Fontana, Alessandro-Scheicher, Martin (2010), An Analysis of Euro Area Sovereign CDS, European Central Bank WorkingPaper Series, 1271.

Fung, HungGay - Sierra, Gregory E. -Yau, Jot-Zhang, Gaiyan. (2008). “Are the U.S. Stock Market and Credit Default Swap Market Related? Evidence from the CDX Indices, Journal of Alternative Investments, 11 (1), pp.43-61.

Gapen, Michael -Gray, DaleLim, Cheng H.-Xiao, Yingbin (2008),Measuring and Analyzing Sovereign Risk with Contingent Claims. IMF StaffPapers, 55(1), pp. 109-148.

Göktaş, Özlem (2005), Teorik ve Uygulamalı Zaman Serileri Analizi, İstanbul: Beşir Kitabevi. 
Göktaş Yılmaz, Özlem (2005),“ Türkiye Ekonomisinde Büyüme ile İşsizlik Oranları Arasındaki Nedensellik İlişkisi’”, İstanbul Üniversitesi İktisat Fakültesi Ekonometri ve İstatistik Dergisi, 2, ss.11-29.

Gün, Musa (2018), “TheCo-Movement of Credit Default Swaps and Stock Markets in Emerging Economies", Recent Perspectives and Case Studies in Finance andEconometrics, First Adition, pp.55-69.

Hanc1, Görkem (2014), “Kredi Temerrüt Takasları ve BİST-100 arasındaki ilişkinin incelenmesi’', Maliye Finans Yazıları, 28 (102), ss.9-22.

Hull, John C. (2008), Options, Futures and Other Derivatives (7th Edition), PrenticeHall, UpperSaddle River.

Jeanneret, Alexandre (2017), “ SovereignDefault Risk andthe U.S. Equity Market”, Journal of Financial and Quantitative Analysis, 52(1), pp.305-339.

Kayhan, Selim - Adıgüzel, Uğur - Bayat Tayfur (2016), CDS Primlerinin Borsa Endeksleri Üzerindeki Etkisi: BİST-100 Örneği, 17.Uluslararası Ekonometri, Yöneylem Araştırması ve İstatistik Sempozyumu Bildiriler Kitabı, Cumhuriyet Üniversitesi Ekonometri Bölümü, 2-4 Haziran, Sivas, ss.290-293.

Kaminsky, Graciela L. -Reinhart, Carmen-Vegh, Carlos A. (2003),“ TheUnholyTrinity of Financial Contagion', Journal of EconomicPerspectives 17(4), pp.51-74.

Kendirli, Selçuk - Çankaya, Muhammet (2016), “Döviz Kuru Ve Enflasyonun BİST Banka Endeksi Üzerindeki Etkisi”, MANAS Sosyal Araştırmalar Dergisi, 5(3), ss.217-227.

Kılc1, Esra N. (2017), “CDS Primleri İle Ülke Kredi Riski Arasındaki İlişkinin Değerlendirilmesi; Türkiye Örneği’’, Maliye Finans Yazıları, 108, ss.71-86.

Kiyotaki, Nobuhiro- John Moore(2005), “Financial Deepening”, Journal of European Economic Association: Papersand Proceedings. No. 3, pp.701-713.

Kunt, Abdullah S. - Taş, Oktay (2008), “Kredi Temerrüt Swapları Ve Türkiye'nin CDS Priminin Tahmin Edilmesine Yönelik Bir Uygulama’’. İTÜ Dergisi 5(1), ss.78-89.

Kliber, Agata (2011), "Sovereign CDS Instruments in Central Europe-link Ages and Interdependence', Dynamic Econometric Models, 11, pp.111-128.

Johansen, Soren (1988)," The Mathematical Structure of Error Correction Models,, Contemporary Mathematics, 80, pp.359-386.

Johansen, Soren (1988), "Statistical Analysis Of Cointegrationvectors', Journal of Economic Dynamics and Control, 12, pp.231-254.

Johansen, Soren-Juselius, Katarina (1990),“ Maximum LikelihoodEstimationandInference on Cointegration, Oxford Bulletin of Economics and Statistics',Oxford Bulletin of Economics and Statistics, 52(2), pp.169-210. 
Loffler, Gunter (2003),“ The Effects of EstimationError on Measures of Portfolio Credit Risk, Journal of Bankingand Finance, Journal of Bankingand Finance, 27(8), pp.1427-1453.

Gatarek, Lukasz-Wojtowicz, Martin (2015),The Relation between Sovereign Credit Default Swap Premium and Banking Sector Risk in Poland, Narodowy Bank PolskiWorkingPaper No: 222.

Gujarati, Damodar N. -Porter, Dawn C (2009),Basic Econometrics, McGraw-HillIrwin, Boston.

Mataev, Miroslav (2012),“ The Effect of Sovereign Credit Rating Announcements on Emerging Bond and Stock Markets: New Evidences, Oxford Journal: An International Journal of Business andEconomics, 7(1), pp. 28-41.

Mataev, Miroslav-Marinova, Elena (2019), “ ),Relation between Credit Default Swap Spreads and Stock Prices: A Non-linear Perspective, Journal of Economicsand Finance, 43(1), pp.1-26.

Mensi, Walid -Hammoudeh, Shawkat-Yoon, Seong-Min (2016), “Asymmetric Linkages Between BRICS Stock Returnsand Country Risk Rratings: Evidence from Dynamic Panel Threshold Models,, Review of International Economics, 24(1), pp.1-19.

Merton, Robert C. (1974), “On Thepricing Of Corporatedebt: The Risk Structure Of Interestrates", The Journal of Finance, 29(2), pp.449-470.

Miranda, Rodrigo C - Tabak, Benjamin M. -Mederious J. Mauricio (2012),Contagion in CDS, Banking and Equity BMarkets,The Banco Central do Brasil, Working Paper No: 293.

Norden, Lars-Weber, Martin (2009),“ The Co-movement of CreditDefault Swap, Bond and Stock Markets: An Empirical Analysis, European Financial Management, 15 (3), pp.529-562.

Pedroni, Peter (2000), Fully Modified OLS for Heterogeneous Cointegrated Panels, Department of EconomicsWorking Papers 2000-03, Department of Economics, Williams College.

Realdon, Marco (2008),“ CreditDefault Swap RatesandStockPrices”, Applied Financial EconomicsLetters. 4 (4), pp.241-248.

Shear, Falik -Butt, Hilal A. - Badshah, Imtiaz (2017), An Analysis of The Relationship Between the Sovereign Credit Default Swap sand The Stock Market of Pakistan through Handling Outliers, 8th Economicsand Finance Conference, London, pp.143159 .

Sovbetov, Yhlas- Saka, Hami (2018), “'Doesit Taketwoto Tango: Interaction Between Credit Default Swap sand National Stock Indices,', Journal of Economicsand Financial Analysis, 2 (1), pp.129-149. 
Tarı, Recep - Yıldırım, Durmuş Ç. (2009), ‘Döviz kuru belirsizliğinin ihracata etkisi: Türkiye için bir uygulama”, Yönetim ve Ekonomi, 16(2), ss.95:105.

Yapraklı, Sevda - Güngör, Bener (2007), “Ülke Riskinin Hisse Senedi Fiyatlarına Etkisi: İMKB-100 Endeksi Üzerine Bir Araştırma', Ankara Üniversitesi SBF Dergisi, 62, ss.199- 218.

Yenice, Sedat - Hazar, Adalet (2015). “Gelişmekte Olan Ülkelerdeki Risk Primleri İle Menkul Kıymet Borsalarının Etkileşiminin İncelenmesi”, Journal of Economics, Finance and Accounting, 2 (2), ss.135-151. 